http://jmscr.igmpublication.org/home/ ISSN (e)-2347-176x ISSN (p) 2455-0450

crossref DOI: https://dx.doi.org/10.18535/jmscr/v7i9.43

Journal Of Medical Science And Clinical Research

\title{
Efficacy of Gargling the Green tea Solution to the Level of pH Saliva on Teenager Students Population in Deli Serdang District of Indonesia
}

\author{
Authors \\ Manta Rosma, Rosdiana Tiurlan Simaremare, Kirana Patrolina Sihombing* \\ Dental Hygienis Department, Medan Health Polytechnics of Ministry of Health, Medan, Indonesia \\ *Corresponding Author \\ Kirana Patrolina Sihombing
}

\begin{abstract}
Objectives: Green tea contains have antimicrobial, anticariogenic and therapeutic effects on several diseases. The goal of this research to determine the effect of gargling the green tea solution on salivary pH on teenage students population. This research is a Quasy experiment with a pre-post test randomized single blind control trial design.

Methods: Interventions include gargling green tea solution and measuring the $p H$ saliva before and after intervention. The sample consisted of 60 subjects, divided into 3 groups consist of 20 respondents. Saliva was measured by a Hanna digital pH meter. Statistical analysis using Kruskal Wallis and Wilcoxon test. Significance is indicated by the value of $p<0.05$ with a confidence level of $95 \%$.

Results: It showed that the data were not normally distributed ( $p<0.05)$. There was a significant difference between salivary $p H$ before and after gargling green tea solution ( $p<0.05)$. Based on the Kruskal Wallis test, there was a significant difference between the control group and gargling with green tea solution group.

Conclusion: It was concluded that Gargling with $20 \mathrm{ml}$ green tea solution more effective than $30 \mathrm{ml}$ group. The suggestion was gargling with green tea solution was helpful to neutralize the saliva $\mathrm{pH}$ to inhibits the process of dental caries.

Keywords: Green Tea, Saliva pH, Gargling.
\end{abstract}

\section{Introduction}

Saliva is a biological liquid in the oral cavity which is a mixture of major and minor salivary gland secretions with the composition of organic, inorganic and macromolecular materials (Fabian et al, 2007) Saliva is an important factor to maintain mineral balance and oral health (Almeida et al, 2008; Wu et al, 2008)). The condition of saliva affects the formation of plaques andtartar, especially against supragingival tartar (Jin and Yip, 2002).
Over time, studies about green tea has the potential to prevent dental and oral diseases. Green tea contains catechins (polyphenol compounds) which have antimicrobial, anticariogenic and therapeutic effects on some diseases (Taylor, 2005). Green tea is also proven effective against periodontal disease, oral cancer, halitosis and preventing dental caries.

Various benefits of green tea can not be separated from the presence of beneficial compounds such as polyphenol, theophylline, tannin, catechins, and 
a number of minerals such as $\mathrm{Zn}, \mathrm{Se}, \mathrm{Mo}$, fluoride, minerals that can prevent inflammation of the gums and cavities. Polyphenols may reduce plaque and acid production by oral bacteria that cause caries and gum disease. Green tea is also proven effective against periodontal disease, oral cancer, halitosis and preventing dental caries (Arab et al., 2011).

Every milliliter of saliva 10-200 million bacteria are found, one of which is Streptococcus Mutans (Tarigan, 2013). Streptococcus mutans bacteria that multiply will cause the formation of plaque in the enamel layer and will cause the $\mathrm{pH}$ of the oral cavity to decrease, become acidic, while reducing the Streptococcus mutans bacteria in the oral cavity causes to become alkaline and even neutral. The lower of the $\mathrm{pH}$ value of saliva, the more acid in the solution. Conversely, the increase in salivary $\mathrm{pH}$ value based on the background of green tea containing catechin compounds, where this substance plays a role in inhibiting the growth of streptococcus mutans.

The aim of this study was to determine the effect of gargling with green tea solution on salivary $\mathrm{pH}$ in teenage students population in deli serdang district of indonesiaand to find out the difference in average salivary $\mathrm{pH}$ difference before and after gargling $20 \mathrm{ml}$, and $30 \mathrm{ml}$ green tea solution.

\section{Methods}

\subsection{Research Design}

This research is a Quasy experiment with a prepost test randomized single blind control trial design (Arikuntoro 2006). In this study the interventionwas gargling the green tea solution and measured saliva $\mathrm{pH}$ before and after intervention. In this study the sample consisted of 60 subjects, which divided by simple random sampling using random number tables, and divided into 3 groups consist of 20 people.

1. Group I : The untreated (control) group who was given drinking water by blind coloring according to the color of green tea to disguise the respondent.
2. Group II : The treatment group gargling with $20 \mathrm{ml}$ green tea solution.

3. Group II : The treatment group gargling with $30 \mathrm{ml}$ green tea solution.

\subsection{Research Locations}

This research was carried out in several locations. Data was collect by oral cavity examination and taking the saliva while salivary $\mathrm{pH}$ measurements were carried out in the Laboratory

\subsection{Research Population and Samples}

The population is all teenage students with total 400 peoples. Sampling was done by consecutive sampling method according to inclusion and exclusion criteria The inclusion criteria were willing to fill out informed consent, was not in sick condition, cooperatively, the composition of the teeth were not crowded or the teeth were lightly packed and carious teeth had a maximum of 2 teeth, while the exclusion criteria were not in orthodontic treatment or prosthetic use.

\subsection{Research instrument}

Instruments used were $\mathrm{pH}$ meters, collecting pot saliva, diagnostic set (windshield, tweezers, near becken), check sheets, stopwatches, ice boxes, water thermometers, green tea solution, masks, gloves, aquades, and ice gels.

\subsection{Measurement}

The primary data is the salivary $\mathrm{pH}$ data that has been taken by the direct-mouth examination technique of the students while the secondary data is the data needed as a complement in the research obtained from the school, namely data on the number of students.

\subsection{Implementation Research}

Preparation stage: Make a green tea solution with a volume of $20 \mathrm{ml}$ and $30 \mathrm{ml}$. Green tea solution was made using green tea dipping as much as $8 \mathrm{gr}$ (4 bags) with $320 \mathrm{ml}$ of distilled water so that a $2.5 \%$ green tea solution obtained by brewing process carried out at the optimum temperature of $70-80^{\circ} \mathrm{C}$ so that the levels of polyphenols in green tea are not reduced (Nubatonic et al., 2016). Every $20 \mathrm{ml}$ of green tea solution is made from mixing green tea with a concentration of $2.5 \%$ plus $17.5 \mathrm{ml}$ of distilled water, while every $30 \mathrm{ml}$ 
of green tea solution is made from mixing green tea with a concentration of $2.5 \%$ and added 27.5 $\mathrm{ml}$ of distilled water. The control solution was made from mixing $30 \mathrm{ml}$ of distilled water mixed with green food coloring until the color was similar to the color of the green tea solution.

Phase :

1. Early Saliva is carried out 1 hour after consumed food snacks as usual. After 30 minutes of resting hours the patient is not allowed to eat and drink. Respondents were instructed to sit in an upright position with their heads slightly bent forward, to help collect saliva in 5 minutes. Respondents were asked to spit out saliva into the collecting pot saliva for 5 minutes until 1-2 $\mathrm{ml}$ of saliva was obtained.

2. The collected saliva is stored in a closed pot container which is labeled (with sample code for each different group), stored in ice box filled with ice gel, and immediately taken to the laboratory.

3. Gargling green tea solution $(20 \mathrm{ml}, 30 \mathrm{ml}$, control) is done for 30 seconds strongly by sucking fluid between the teeth, around the mouth with movement of the muscles of the lips, tongue, and cheeks closed.

4. Measuring stage: Saliva $\mathrm{pH}$ is measured using a $\mathrm{pH}$ meter until all $\mathrm{pH}$ meter electrodes are submerged in saliva. Then the salivary $\mathrm{pH}$ is recorded on the data sheet provided.

\subsection{Data analysis}

If the data is normally distributed (SaphiroWilk test) so statistical analysisis used a one-way ANOVA test to compare each parameter between the three intervention groups, while the dependent $t$ test to compare before and after intervention in each group. Significance is indicated by the value of $p<0.05$ with a confidence level of $95 \%$.

\section{Result}

The data were tested for normality by the Shaphiro-Wilk test, shows that the data is not normally distributed, as presented in table 1 below.
Table 1. Normality test of Saliva $\mathrm{pH}$

\begin{tabular}{|l|c|c|c|}
\hline & Group & $\mathrm{n}$ & $p$ \\
\hline Pre (Before) & I & 20 & 0,012 \\
& II & 20 & $0,823^{*}$ \\
& III & 20 & 0,034 \\
\hline Post (After) & I & 20 & $0,085^{*}$ \\
& II & 20 & $0,268^{*}$ \\
& III & 20 & $0,70^{*}$ \\
\hline
\end{tabular}

$*=$ Homogeneous data $(\mathrm{p}>0,05)$

Table 1 shows that data is not normally distributed ( $\mathrm{p}<0.05)$ so the data was tested using nonparametric test, the Wilcoxon test, and the Kruskal Wallis test

Table 2. Baseline

\begin{tabular}{|l|c|c|c|c|}
\hline Variable & I & $\begin{array}{c}\text { II } \\
(20 \mathrm{ml})\end{array}$ & $\begin{array}{c}\text { III } \\
(30 \mathrm{ml})\end{array}$ & \multirow{2}{*}{-value } \\
\cline { 2 - 4 } & Mean \pm SD & $\begin{array}{c}\text { Mean } \pm \\
\text { SD }\end{array}$ & $\begin{array}{c}\text { Mean } \pm \\
\text { SD }\end{array}$ & \\
\hline Before & $6,9 \pm 0,48$ & $6,76 \pm$ & $6,9 \pm$ & 0,303 \\
& & 0,38 & 0,32 & \\
\hline
\end{tabular}

The results of statistical tests in table 2 show that the initial conditions of salivary $\mathrm{pH}$ before intervention in each group did not different $(p>$ $0.05)$. It means that the initial conditions of all respondents are the same (homogeneous). Based on the table above the initial average value of saliva $\mathrm{pH}$ of the three groups lest than 7 which shows the acidic conditions

Table 3. Average Saliva for each group (based on the Wilcoxon test)

\begin{tabular}{|c|c|c|c|c|}
\hline Saliva $\mathrm{pH}$ & $\mathrm{n}$ & Mean+ SD & $\Delta$ & p-value \\
\hline $\begin{array}{l}\text { Control group } \\
\text { Before } \\
\text { After }\end{array}$ & $\begin{array}{l}20 \\
20\end{array}$ & $\begin{array}{c}6,9 \pm 0,48 \\
6,95 \pm 0,51\end{array}$ & 0,35 & 0,072 \\
\hline $\begin{array}{l}\text { II }(20 \mathrm{ml}) \\
\text { Before } \\
\text { After }\end{array}$ & $\begin{array}{l}20 \\
20\end{array}$ & $\begin{array}{l}6,76 \pm 0,38 \\
7,32 \pm 0,37\end{array}$ & 0,68 & $0,000 *$ \\
\hline $\begin{array}{l}\text { III }(30 \mathrm{ml}) \\
\text { Sebelum } \\
\text { Sesudah }\end{array}$ & $\begin{array}{l}20 \\
20\end{array}$ & $\begin{array}{l}6,90 \pm 0,32 \\
7,63 \pm 0,30\end{array}$ & 0,61 & $0,000 *$ \\
\hline
\end{tabular}

$*=$ Significance value $: \mathrm{p}<0,05$

In Table 3 show that there is a significant difference between salivary $\mathrm{pH}$ before and after gargling green tea solution $(\mathrm{p}<0.05)$ in groups II and III, but salivary $\mathrm{pH}$ after gargling green tea in the control group did not significant difference. The average difference between before and after the intervention in the three groups most occurred in group II. It means that group IIhas the biggest 
change in salivary $\mathrm{pH}$ increases compared to groups III and I.

Tabel 4. Post intervention

\begin{tabular}{|l|c|c|c|c|}
\hline Variable & I & II & III & p-value \\
\cline { 2 - 4 } & $\begin{array}{c}\text { Mean } \pm \\
\text { SD }\end{array}$ & $\begin{array}{c}\text { Mean } \pm \\
\text { SD }\end{array}$ & Mean \pm SD & \\
\hline Saliva pH & $6,95 \pm$ & $7,32 \pm$ & $7,63 \pm 0,30$ & $0,000^{*}$ \\
& 0,51 & 0,37 & & \\
\hline$\Delta$ & 0,35 & 0,68 & 0,61 & $0,000^{*}$ \\
\hline
\end{tabular}

Based on table 4 above shows there is significant differences in the average salivary $\mathrm{pH}$ after intervention $(\mathrm{p}<0.05)$. Based on the Kruskal Wallis test also found the average difference in salivary $\mathrm{pH}$ of the three groups was also significantly different. Salivary $\mathrm{pH}$ values of the three groups included baseline criteria (greater than7) but among the three groups, groups II and III were more basic than the control group.

Figure 1. Graph of differences in salivary $\mathrm{pH}$ of each group before and after intervention

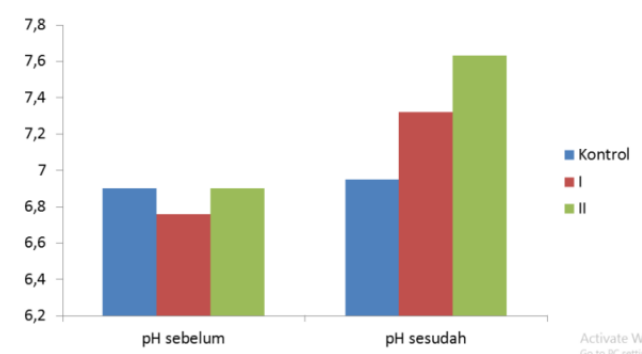

Based on the graph above the Saliva $\mathrm{pH}$ of the intervention group increased compared to the control group. The salivary $\mathrm{pH}$ of the intervention group included baseline criteria.

\section{Discussion}

Based on the Wilcoxon test showed there were significant differences between salivary $\mathrm{pH}$ data before and after gargling green tea solution ( $p$ $<0.05$ ), so it can be said that gargling with a green tea solution has an effect on changes in salivary $\mathrm{pH}$. Based on the Kruskal Wallis test, the treatment group produced a better increase in salivary $\mathrm{pH}$ than the control group. In group II the average difference in increase in salivary $\mathrm{pH}$ was 0.68 , higher than the average difference in group III (0.61); whereas in the average control group the difference in increase in salivary $\mathrm{pH}$ was smaller than group II and III. It means that $20 \mathrm{ml}$ of green tea has more influence on salivary $\mathrm{pH}$ than the $30 \mathrm{ml}$ green tea solution group. Based on the Kruskal Wallis test it was found that there were significant differences in the mean differences between the three groups ( $p<0.05)$.

An enhancement salivary $\mathrm{pH}$ happen because of the salivary secretion. This causes an increase in bicarbonate ions so that the salivary $\mathrm{pH}$ will increase. Increased salivary secretion can occur due to mechanical and chemical stimulation of the salivary gland and from stimulating the steeping content of green tea, which is bitter. This is in accordance with Permatasari's study (2011), which showed an increase in salivary secretion in the gargling group of green tea due to mechanical stimulation of the salivary glands (gargling). As a result, salivary $\mathrm{pH}$ in the treatment group increased significantly compared to the control group.

Green tea has a polyphenol compound which consists mostly of catechins. Catechins from green tea work to inhibit the activity of glycotransferase enzymes, thus inhibiting the attachment of bacteria to the pellicle and the process of plaque formation is also hampered (Tehrani et al., 2011). Polyphenols also work to inhibit the growth of microorganisms because they have the ability to denaturate cell proteins and damage cell membranes of microorganisms on dental plaque (Anggayanti et al., 2013). Research conducted by Wijaya and Samad (2004) found that green tea solution has the ability to inhibit the development of Streptococcus mutans with a minimum concentration (MIC) is $2.5 \%$. Research conducted by Awadala (2011) states that gargling with a solution of unsweetened green tea can inhibit the growth of Streptoccocusmutans bacteria on plaque and saliva which are the main bacteria that cause dental caries. Another study of green tea conducted by Fajriani (2014) states that gargling with $2.5 \%$ of green tea solution has the same effectiveness as $0.2 \%$ chlorhexidine in reducing Streptococcus mutans colonies in saliva in vitro. 
Salivary $\mathrm{pH}$ is influenced by buffer capacity, average salivary rate, and oral microorganisms. Salivary pHat $6.5-7.5$ is the optimal for bacterial growth and oral $\mathrm{pH}$ at 4.5-5.5 can facilitate the growth of acidogenic bacteria such as Streptococcus mutans and Lactobacillus. Green tea contains catechins (polyphenol compounds) which are proven to have antimicrobial, anticariogenic and therapeutic effects on several diseases. Green tea is also proven effective against periodontal disease, oral cancer, halitosis and preventing dental caries.

\section{Conclusion}

The average difference in salivary $\mathrm{pH}$ of the three groups was significantly different. Gargling with $20 \mathrm{ml}$ green tea solution is more effective than 30 $\mathrm{ml}$ green tea solution to neutralize salivary $\mathrm{pH}$.

\section{Competing Interests Statement}

The author declare that there are no competing or potential conflict of interest regarding the publication of the paper.

\section{Acknowledgment}

The author express their gratitude to all the staff members of the laboratory Terpadu of University of sumatera utara for supporting the present research with technical effords and time.

\section{Conflict of Interest}

The authors involved in this research declare no conflict of interest.

\section{References}

1. Almeida et al.,2008. Saliva Composition and Functions : a Comprehensive Review. The Journal of Contemporary Dental Practice.9 : 2-6

2. Anggayanti NA, Adiatmika IPG, Adiputra $\mathrm{N}, 2013$. Gargling with black tea is more effective than chlorhexidinegluconate $0.2 \%$ to reduce dental plaque accumulation. PDGI Journal Vol 6(2): pp $35-40$.
3. Arab H, Maroofian A, Golestani S, Shafaee H, Sohrabi K, 2011. Review of the therapeutic effects of camellia sinensis. Plants Res. Vol 5(23): 5465-9.

4. Arif MS. Tea and Its Benefits for Health. Yogyakarta: Kaninus, 2003.

5. Awadala HI, Ragab MH, Bassuoni MW, Fayed MT, Abbas MO, 2011. A pilot study of the role of green tea use on oral health. Int J Dent Hyg.;9(2):110-6.

6. Fajriani, Andriani JN, 2014. Reduction of salivary streptococcus mutans colonies in children after rinsing with $2.5 \%$ green tea solution. Journal of Dentistry Indonesia. Vol 21(3):81-6.

7. Jin dan Yip, 2002. Supragingival calculus : formation and control. Crit Rev Oral Biol Med.Vol 13(5) : 426-41.

8. Nubatonis ND, Gunawan PN, Wuisan J, 2016. The effect of gargling green tea solution in reducing plaque accumulation in the teeth of children aged 8-10 years, Jurnal e-Gigi, Vol. 4 no.2, p.183-7.

9. Riskesdas, 2013. Jakarta, Indonesia: Health Research and Development Agency of the Ministry of Health Indonesia republic, pp. 119.

10. Taylor PW, Miller JMTH, Stapleton PD, 2005. Antimicrobial properties of green tea catechins. Europe PMC Funders Group. Vol 2:71-81

11. Tehrani MH, Asghari G, Hajiahmadi M, 2011. Comparing Streptoccocus mutans and Lactobacillus colony count changes following green tea mouth rinse or sodium fluoride mouth rinse use in

12. Wijaya D, Samad R, 2004. The inhibition of black tea, green tea, and oolong tea on the growth of Streptococcus mutans.PDGI Journal.Vol 55:82-7. 